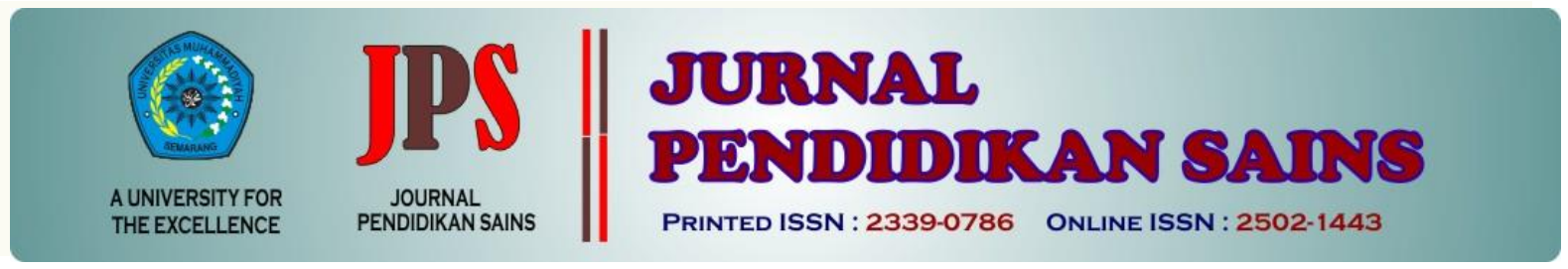

http://jurnal.unimus.ac.id/index.php/JPKIMIA

\title{
PENERAPAN MEDIA PEMBELAJARAN KIMIA BERBASIS SCIENCE, TECHNOLOGY, ENGINEERING, AND MATHEMATICS (STEM) UNTUK MENINGKATKAN HASIL BELAJAR SISWA SMA/SMK PADA MATERI REAKSI REDOKS
}

Oleh:

Laily Yunita Susanti ${ }^{1}$, Rafiatul Hasanah ${ }^{1}$, Muhammad Habbib Khirzin ${ }^{2}$

${ }^{1}$ Tadris IPA Fakultas Tarbiyah dan Ilmu Keguruan IAIN Jember

${ }^{2}$ Teknologi Pengolahan Hasil Ternak Politeknik Negeri Banyuwangi

\begin{tabular}{ll}
\hline \multicolumn{2}{l}{ Article history } \\
\hline Submission & $: 2018-03-27$ \\
Revised & $: 2018-09-12$ \\
Accepted & $: 2018-09-18$
\end{tabular}

Keyword:

Reaksi redoks, media pembelajaran kimia,

Science Technology

Engineering and

Mathematics (STEM)

\begin{abstract}
The aims of this research was to determine the effect of using Science, Technology, Engineering, and Mathematics (STEM) based learning media on chemistry learning outcomes of Redox Reaction Topic in State Senior or Vocational High School Student. Research method was experimental design which consisted of development and impelementation of learning media. STEM learning media being developed were $\mathrm{CO}_{2}$ gas sensor and learning modul as the guidance of learning process. STEM learning media were valid based on the evaluation which was conducted by chemistry and learning media expert. Field tesing of STEM learning media was conducted on 20 students of SMKN 5 Surabaya dan SMAN 16 Surabaya. Learning process by using STEM learning media on Redox Reaction topic was conducted on 66 students of SMKN 5 Surabaya dan SMAN 16 Surabaya. Result of research showed that there ware a differences beetwen cognitif and affective learning outcomes.
\end{abstract}

\section{Pendahuluan}

Ilmu kimia merupakan bagian dari sains sehingga dalam perwujudannya pembelajaran kimia tidak pernah terlepas dari proses pembelajaran sains. Pembelajaran sains berbasis pada masalah atau problem-based learning (PBL), yaitu metode pembelajaran berbasis pendekatan konstruktivis dimana siswa menjadi pusat pembelajaran dan memecahkan permasalahan dalam kehidupan berdasarkan pengetahuan yang dimiliki secara bersama-

*Corresponding Author:

$\begin{array}{ll}\text { Nama } & \text { : Laily Yunita Susanti } \\ \text { Lembaga } & \text { : IAIN Jember } \\ \text { Email } & \text { : lailyirzi@gmail.com }\end{array}$

sama dalam grup atau tim (Juan dan Molina, 2011).

Oleh karena pembelajaran sains berbasis pada masalah, maka pembelajaran sains yang ideal merupakan pembelajaran berbasis laboratorium (laboratory-based learning).

Berkaitan dengan aktivitas siswa pada pembelajaran sains maka diperlukan laboratorium yang berfungsi sebagai tempat untuk memberikan pengalaman belajar dimana siswa berinteraksi dengan bahan dan atau dengan model secara langsung serta sebagai sarana pendukung untuk berlangsungnya 
eksperimen (Handelsman dkk, 2010; Omosewo, 2006). Pemenuhan kebutuhan sarana laboratorium dalam bidang sains akan lebih efektif apabila dilakukan pengembangan sarana laboratorium. Laboratorium dapat diperkaya dengan perangkat berbasis teknologi, khususnya komputer, untuk memudahkan akuisisi data dan analisis (Anderson, 2013). Laboratorium yang diperkaya dengan perangkat teknologi dapat dimanfaatkan untuk mendukung pembelajaran sains, khususnya pembelajaran kimia terintegrasi.

Pembelajaran kimia terintegrasi erat kaitannya dengan kurikulum 2013 yang dirancang dengan tujuan agar siswa mampu mengembangkan sikap, pengetahuan, dan keterampilan serta menerapkannya dalam berbagai situasi di sekolah dan masyarakat. Kurikulum tersebut dikembangkan berdasarkan penyempurnaan pola pikir pembelajaran dari ilmu pengetahuan tunggal (monodiscipline) menjadi pembelajaran ilmu pengetahuan jamak (multidisciplines) atau pembelajaran terintegrasi. Pembelajaran terintegrasi sangat menguntungkan, dimana siswa dituntut untuk berpikir secara mendalam dan kreatif karena terkait langsung dengan satu bidang ilmu dan bidang ilmu yang lain (Depdikbud, 2013). Berkaitan dengan pembelajaran kimia terintegrasi, terdapat suatu pendekatan dalam pembelajaran yang dapat mengintegrasikan ilmu kimia dengan ilmu lainnya (Lantz, 2009).

Pendekatan dalam pembelajaran yang dapat mengintegrasikan ilmu kimia dengan ilmu lainnya adalah science, technology, engineering and mathematics (STEM) (ITEA, 2009: Lantz, 2009; Hanover Research, 2011). STEM merupakan pendekatan dalam pembelajaran yang terintegrasi dengan berbagai disiplin ilmu. STEM memungkinkan siswa untuk mempelajari konsep akademik secara tepat dengan menerapkan 4 disiplin ilmu (sains, teknologi, keahlian teknik dan matematika). STEM memiliki beberapa karakteristik diantaranya berbasis teknologi, kinerja (performance-based), berbasis inkuiri, dan berbasis pada masalah atau problem-based learning (ITEA, 2009; Chi, H., dan Jain, H., 2011). Pembelajaran berbasis STEM juga menuntut siswa untuk menjadi inovator (pembaharu), pemecah masalah, dan penemu yang percaya diri, sadar teknologi, serta mampu berpikir logis. Dalam proses pembelajaran berbasis STEM digunakan sistem penilaian formatif dan sumatif berupa tes tulis untuk penilaian kompetensi pengetahuan dan tes kinerja untuk penilaian kompetensi keterampilan (Lantz, 2009).

Beberapa penelitian menunjukkan bahwa pembelajaran berbasis STEM dengan menggunakan media pembelajaran diterapkan dalam pendidikan formal. Barrett et. al. (2014) menggunakan modul meteorologi dan keteknikan untuk mengedukasikan bahaya meteorologi dan keteknikan dari angin tornado. Peningkatan skor rata-rata pertanyaan dalam instrumen adalah $40,2 \%$ setelah penerapan modul pembelajaran. Hinze et.al. (2013) meneliti penerapan pembelajaran berbasis STEM untuk pembelajaran pada mata kuliah Kimia Organik di Universitas Texas. Pembelajaran STEM dilakukan dengan memvisualisasikan bentuk molekul menggunakan ball-and-stick models dan program electrostatic potensial maps (EPMs). Penelitian lain dilakukan oleh Nugent et. al. (2010) dengan menerapkan teknologi robotik dan geospasial dalam pembelajaran. Berdasarkan penelitian ini, sistem pengukuran hasil belajar dalam pembelajaran STEM menggunakan pre tes, pos tes dan angket sikap untuk menilai motivasi siswa.

Berkaitan dengan pembelajaran kimia terintegrasi berbasis STEM, diperlukan sarana laboratorium yang praktis dan mudah pengoperasiannya. Sarana laboratorium yang dapat dikembangkan sebagai penunjang pembelajaran berbasis STEM merupakan sarana laboratorium yang terintegrasi dengan teknologi secara aktual. Terdapat berbagai macam teknologi yang telah dikembangkan sebagai sarana edukasi, di antaranya penggunaan software komputer sebagai media belajar, game edukasi (Klopfer et. al., 2009; Prasetyo et. al., 2014), teknologi sensor (Srisawasdi, 2012) pembelajaran online, dan virtual laboratorium (Johnson, et. al., 2013).

Hasil penelitian terdahulu mengenai penerapan media pembelajaran berbasis STEM membuat peneliti tertarik untuk menerapkan media pembelajaran STEM pada pembelajaran kimia terintegrasi utnuk materi reaksi redoks. Penelitian ini menekankan pada penggunaan teknologi sensor sebagai media pembelajaran berbasis STEM. Teknologi sensor yang dikembangkan berupa sensor gas. Penggunaan rangkaian sensor gas sebagai media pembelajaran mengintegrasikan beberapa bidang ilmu, yaitu bidang sains (kimia dan fisika), matematika dan teknologi. Interaksi antarmuka sensor dengan gas target atau gas 
yang dideteksi (berupa gas pereduksi ataupun pengoksidasi) akan menyebabkan terjadinya reaksi redoks antara gas target dengan permukaan sensor (Wetchakun et. al., 2011; Liu, et. al., 2012; Petrucci, 2011).

Proses kimia yang berlangsung di dalam sensor akan menyebabkan adanya aliran elektron. Aliran elektron dalam sensor menyebabkan perubahan tegangan ataupun tahanan listrik sehingga proses ini melibatkan ilmu fisika (Figaro Engineering Inc., 2004). Sedangkan proses visualisasi data digital keluaran sensor dalam bentuk tabel maupun grafik fungsi melibatkan ilmu matematika (Putra, 2013). Selanjutnya penggunaan program komputer Microsoft Excel untuk membuat aplikasi yang dapat memvisualisasikan data digital keluaran sensor melibatkan ilmu komputer (teknologi). Konstruksi konsep reaksi redoks dalam pembelajaran kimia umumnya dimulai dari istilah reaksi reduksi dan oksidasi karena kedua reaksi tersebut berlangsung secara simultan (Shehu, 2015). Melalui visualisasi nyata reaksi redoks yang terjadi pada permukaan sensor, siswa diharapkan dapat mengkonstruksi pemahaman mengenai reaksi redoks secara mandiri dalam bentuk pembelajaran kimia terintegrasi.

Berdasarkan uraian tersebut, maka penelitian ini bertujuan untuk: (1) menguji kelayakan media pembelajaran kimia berupa rangkaian sensor gas karbondioksida $\left(\mathrm{CO}_{2}\right)$ dan modul STEM dengan topik reaksi redoks, (2) menganalisis pengaruh penggunaan media pembelajaran berbasis STEM terhadap hasil belajar kognitif, afektif, dan psikomotor siswa pada topik reaksi redoks.

$\begin{array}{ll}* \text { Corresponding Author: } \\ \text { Nama } & \text { : Laily Yunita Susanti } \\ \text { Lembaga } & : \text { IAIN Jember } \\ \text { Email } & : \text { lailyirzi@gmail.com }\end{array}$

\section{Metode Penelitian}

Jenis Penelitian

Penelitian ini merupakan penelitian eksperimen dengan menggunakan pendekatan deskriptif kuantitatif.

Waktu dan Tempat Penelitian

Penelitian dilaksanakan pada bulan April sampai dengan Juli 2015 di SMKN 5 Surabaya dan SMAN 16 Surabaya.
Target/Subjek Penelitian

Subjek penelitian merupakan siswa kelas $\mathrm{X}$ jurusan Kimia Analisis SMKN 5 Surabaya dan siswa kelas $X$ SMAN 16 Surabaya. Penelitian ini menggunakan desain penelitian eksperimen dengan 1 kelas kontrol dan 1 kelas eksperimen. Sampel diambil dengan teknik pemilihan random cluster sampling.

Prosedur

\section{Tahap 1. Penyusunan media dan modul pembelajaran kimia berbasis STEM}

Penyusunan media pembelajaran STEM berupa sistem pendeteksi gas yang dilengkapi modul interaktif dimulai dari analisis kurikulum 2013 dan pentingnya pengembangan media pembelajaran pada materi Reaksi Redoks. Pengembangan media pembelajaran sangat penting karena dapat memotivasi dan memudahkan siswa dalam pemahaman konsepkonsep kimia. Berdasarkan analisis KI dan KD pada materi reaksi redoks dapat diidentifikasi indikator dan sub-sub materi pembelajaran secara umum.

\section{Tahap 2. Penyusunan instrumen penilaian}

Analisis kurikulum digunakan sebagai dasar untuk menyusun aktivitas pembelajaran dalam bentuk praktikum, diskusi, dan studi literatur yang disesuaikan dengan karakteristik dan kemampuan awal siswa. Selanjutnya dilakukan penyusunan instrumen penilaian sebagai bagian dari modul interaktif sebagai alat untuk mengetahui ketercapaian indikator dan kompetensi siswa. Instrumen penilaian yang disusun adalah tes tulis untuk penilaian pada ranah kognitif, lembar observasi kinerja untuk penilaian pada ranah psikomotor, dan lembar observasi sikap untuk penilaian pada ranah afektif (sikap).

Tahap 3. Uji coba ahli dan uji coba lapangan media dan modul pembelajaran berbasis STEM

Pada tahap ini dilakukan uji ahli dengan teknik delphi yaitu dengan memilih responden para ahli perancangan model atau produk dalam rangka mereview dan memberikan masukan untuk perbaikan produk. Setelah dilakukan uji coba ahli, uji coba lapangan skala kecil dilakukan terhadap kelompok kecil sebagai pengguna produk.

Tahap 4. Penerapan media dan modul pembelajaran berbasis STEM (Eksperimen)

Jenis eksperimen yang digunakan dalam penelitian ini adalah eksperimen semu. Subjek penelitian terdiri dari 1 kelas kontrol dan 1 kelas eksperimen. Pada kelas eksperimen dilaksanakan proses pembelajaran materi reaksi 
redoks dengan menggunakan media pembelajaran berbasis STEM, sedangkan pada kelas kontrol dilaksanakan proses pembelajaran dengan metode pembelajaran konvensional tanpa media pembelajaran berbasis STEM. Kelompok kontrol dan kelompok eksperimen masing-masing terdiri dari siswa-siswi SMA/SMK yang memiliki pengetahuan awal rendah, pengetahuan awal sedang, dan pengetahuan awal tinggi untuk materi Reaksi Redoks. Pemilihan siswa dengan pengetahuan awal rendah, sedang, dan tinggi didasarkan pada nilai pre tes pada materi Reaksi Redoks. Selain itu, pre tes diberikan di awal pembelajaran untuk mengetahui kesetaraan pengetahuan awal yang dimiliki kelas eksperimen dan kontrol. Setelah proses pembelajaran diberlakukan pos tes untuk mengetahui hasil belajar siswa setelah proses pembelajaran.

Data, Intrumen, dan Teknik Pengumpulan Data

Data yang didapatkan dari hasil penelitian adalah data kualitatif dan data kuantitatif. Data kualitatif berupa hasil validasi media pembelajaran Reaksi Redoks oleh validator. Teknik pengumpulan data dilakukan dengan cara teknik non tes, menggunakan kuesioner/ angket. Instrumen yang digunakan untuk mendapatkan data kualitatif adalah angket berskala Likert untuk validasi media pembelajaran berbasis STEM. Validasi media dilakukan dilakukan oleh 2 dosen kimia dan 2 guru kimia dengan kriteria tertentu. Teknik pengumpulan data dilakukan dengan teknik tes.

Sedangkan data kuantitatif berupa nilai hasil belajar siswa dengan menggunakan media pembelajaran yang dikembangkan. Teknik Instrumen penelitian yang digunakan untuk mendapatkan data kuantitaif adalah butir soal tes materi Reaksi Redoks. Butir soal yang digunakan telah divalidasikan pada 20 siswa kelas X SMAN 16 Surabaya dan SMKN 5 Surabaya. Hasil validasi butir soal menunjukkan bahwa jumlah soal yang layak untuk digunakan sebagai instrumen dalam pembelajaran sebanyak 20 soal pilihan ganda dan 3 soal esai. Butir soal kemudian diujikan pada siswa kelas $\mathrm{X}$ jurusan Kimia Analisis SMKN 5 Surabaya setelah melalui proses pembelajaran dengan menggunakan media pembelajaran berbasis STEM. Hasil belajar siswa kelas kontrol dan eksperimen terdiri dari: (1) hasil belajar kognitif, dengan interval skor 0 s/d 10, (2) hasil belajar afektif, dengan interval skor $0 \mathrm{~s} / \mathrm{d} 4$, dan (3) hasil belajar psikomotor, dengan interval skor $0 \mathrm{~s} / \mathrm{d} 4$.

\section{Teknik Analisis Data}

Data hasil belajar kognitif dan afektif pada siswa kelas eksperimen dan kelas kontrol dianalisis dan dibandingkan untuk mengetahui apakah terdapat perbedaan hasil pembelajaran pada siswa yang mengikuti proses pembelajaran dengan STEM dan metode konvensional. Teknik analisis data hasil belajar kognitif mencakup: (1) analisis pendahuluan (uji normalitas dan uji homogenitas), (2) analisis hasil belajar yang terdiri atas Uji T Sampel Berpasangan (Paired-Sample $T$ Test) dan Independent T-Test. Selisih antara hasil belajar pada awal dan akhir proses pembelajaran (nilai pre tes dan pos tes) untuk kelas kontrol dan eksperimen kemudian di uji $N$-gain untuk mengetahui apakah terdapat perbedaan hasil belajar kognitif yang signifikan pada kedua kelas. Pada hasil belajar afektif juga dilakukan hal yang sama, di mana hasil belajar afektif siswa melalui uji $\mathrm{N}$-gain untuk mengetahui ada tidaknya perbedaan hasil belajar afektif pada kelas kontrol dan eksperimen. Dengan analisis data belajar dapat diketahui perbedaan hasil belajar siswa yang menggunakan media dan modul pembelajaran kimia berbasis STEM dengan siswa yang melalui proses pembelajaran secara konvensional.

\section{Hasil Penelitian dan Pembahasan}

Media pembelajaran STEM divalidasi terlebih dahulu sebelum diujikan pada pembelajaran kimia pada materi reaksi redoks. Berdasarkan Tabel 1 dan 2 dapat diketahui bahwa baik media sensor gas karbon dioksida maupun modul pembelajaran STEM memperoleh kriteria sangat valid. Hal tersebut mengindikasikan bahwa media pembelajaran yang dikembangkan layak digunakan sebagai media pembelajaran kimia berbasis STEM, khususnya untuk materi Reaksi Redoks. Selain itu, modul interaktif STEM sesuai dengan konsep integrasi pembelajaran STEM dan standar isi dalam Kurikulum 2013. Aktivitasaktivitas pembelajaran baik praktikum maupun diskusi, dan soal-soal latihan yang diberikan di dalam modul sesuai dengan desain pembelajaran berbasis masalah (PBL) dan kurikulum 2013. 
Tabel 1. Hasil Validasi Media Sensor Gas $\mathrm{CO}_{2}$

\begin{tabular}{ccccc}
\hline No & $\begin{array}{c}\text { Aspek } \\
\text { Penilaian }\end{array}$ & \multicolumn{3}{c}{ Sensor Gas $\mathrm{CO}_{2}$} \\
\cline { 3 - 5 } & kelayakan isi & 3,34 & 0,486 & $\begin{array}{c}\text { Kringat } \\
\text { valid }\end{array}$ \\
\hline 2 & Sajian & 3,50 & 0,635 & $\begin{array}{c}\text { sangat } \\
\text { valid }\end{array}$ \\
\hline 3 & Kegrafisan & 3,17 & 0,452 & valid \\
\hline 4 & kebahasaan & 3,59 & 0,527 & $\begin{array}{c}\text { sangat } \\
\text { valid }\end{array}$ \\
\hline & Rata-rata $=$ & 3,42 & & $\begin{array}{c}\text { sangat } \\
\text { valid }\end{array}$ \\
\hline
\end{tabular}

Tabel 2. Hasil Validasi Modul Pembelajaran Kimia Berbasis STEM

\begin{tabular}{clccc}
\hline No & $\begin{array}{c}\text { Aspek } \\
\text { Penilaian }\end{array}$ & \multicolumn{3}{c}{$\begin{array}{c}\text { Modul Pembelajaran } \\
\text { STEM }\end{array}$} \\
\cline { 2 - 5 } & $\bar{x}$ & SD & Kriteria \\
\hline 1 & $\begin{array}{l}\text { Kelayakan } \\
\text { isi }\end{array}$ & 3,33 & 0,478 & $\begin{array}{c}\text { sangat } \\
\text { valid }\end{array}$ \\
\hline 2 & Sajian & 3,25 & 0,565 & $\begin{array}{c}\text { sangat } \\
\text { valid }\end{array}$ \\
\hline 3 & Kegrafisan & 3,33 & 0,753 & $\begin{array}{c}\text { sangat } \\
\text { valid }\end{array}$ \\
\hline 4 & Kebahasaan & 3,29 & 0,532 & $\begin{array}{c}\text { sangat } \\
\text { valid }\end{array}$ \\
\hline & Rata-rata $=$ & 3,33 & & $\begin{array}{c}\text { sangat } \\
\text { valid }\end{array}$ \\
\hline & & &
\end{tabular}

Tabel 3 Hasil Uji Hipotesis Kemampuan Awal Siswa

\begin{tabular}{cccc}
\hline \multicolumn{2}{c}{ Rata-rata nilai kelas } & $\begin{array}{c}\text { Nilai } \\
\text { probabilitas }\end{array}$ & Kesimpulan \\
\hline eksperimen & kontrol & \\
\hline 2,93 & 2,85 & 0,619 & Tidak \\
& & & terdapat \\
& & & $\begin{array}{c}\text { perbedaan } \\
\text { yang } \\
\text { signifikan }\end{array}$ \\
\hline
\end{tabular}

Tabel 3 menunjukkan bahwa nilai probabilitas hasil uji hipotesis kemampuan awal siswa yaitu $(0,619)>(0,05)$, sehingga dapat disimpulkan bahwa tidak terdapat perbedaan kemampuan awal antara kelas eksperimen dan kontrol. Selama proses pembelajaran berlangsung dilakukan penilaian kemampuan afektif, kognitif, dan psikomotor untuk mengetahui ketercapaian kompetensi siswa pada kedua kelas.
Tabel 4. Hasil Uji N-gain Hasil Belajar Kognitif Siswa

\begin{tabular}{cccc}
\hline Parameter & $\mathrm{t}_{\text {hitung }}$ & $\begin{array}{c}\text { Nilai } \\
\text { probabilitas }\end{array}$ & Kesimpulan \\
\hline Hasil & 0,922 & 0,026 & $\begin{array}{c}\text { Ada } \\
\text { perbedaan } \\
\text { Belajar }\end{array}$ \\
& & & $\begin{array}{c}\text { yang } \\
\text { signifikan }\end{array}$ \\
\hline
\end{tabular}

Berdasarkan Tabel 4 dapat diketahui bahwa rata-rata nilai hasil belajar kognitif dan afektif kelas eksperimen lebih tinggi dibandingkan kelas kontrol. Hal tersebut dikarenakan media pembelajaran STEM sangat menarik dan memiliki beberapa kelebihan diantaranya berbasis pada masalah atau problem based, mendorong peningkatan kemampuan kognitif, dan mengatur proses pembelajaran siswa (Inel dan Balim, 2013), serta mampu meningkatkan aktivitas siswa dalam kegiatan pembelajaran (Aksela, 2011). Hasil ini sesuai dengan penelitian yang dilakukan oleh Hinze dkk (2013) dan Saxton dkk (2014).

Hasil uji T-independen juga dilakukan terhadap nilai pos tes kelas eksperimen dan kontrol seperti ditunjukkan Tabel 5. Tabel tersebut mengindikasikan bahwa nilai probabilitas $(0,026)<(0,05)$, sehingga dapat disimpulkan bahwa terdapat perbedaan hasil belajar kognitif yang signifikan antara kelas yang mengikuti pembelajaran materi reaksi redoks dengan media pembelajaran berbasis STEM dengan metode konvensional. Tingginya hasil belajar kognitif pada siswa terbentuk setelah pembelajaran dengan menggunakan modul pembelajaran STEM. Modul tersebut menuntun siswa untuk mengkonstruksi konsep reaksi redoks melalui beberapa permasalahan, diantaranya mengenai bagaimana mendefinisikan reaksi reduksi dan oksidasi melalui penggunaan sensor gas untuk mengukur kadar gas $\mathrm{CO}_{2}$ dan bagaimana keterkaitan reaksi redoks dengan kehidupan sehari-hari dan aplikasinya pada suatu sel elektrokimia.

Tabel 5. Hasil Uji N-gain Hasil Belajar Afektif Siswa

\begin{tabular}{cccc}
\hline Parameter & $\mathrm{Z}_{\text {hitung }}$ & $\begin{array}{c}\text { Sig. (2- } \\
\text { tailed) }\end{array}$ & Kesimpulan \\
\hline Hasil & $-2,284$ & 0,022 & $\begin{array}{c}\text { Ada } \\
\text { perbedaan } \\
\text { yelajar }\end{array}$ \\
& & & $\begin{array}{c}\text { yang } \\
\text { signifikan }\end{array}$ \\
\hline
\end{tabular}


Hasil belajar afektif siswa kedua kelas diuji normalitas dan homogenitas sebelum dilakukan uji hipotesis. Berdasarkan uji normalitas dan homogenitas dapat diketahui bahwa data hasil belajar afektif kelas eksperimen dan kontrol tidak terdistribusi normal dan tidak homogen sehingga untuk uji hipotesis tidak dapat digunakan uji $\mathrm{T}$, tetapi digunakan uji Mann Whitney. Tabel 5 menunjukkan bahwa pada uji nilai Mann Whitney, Sig. $(2$-tailed $)<(0,05)$ sehingga dapat disimpulkan bahwa terdapat perbedaan hasil belajar afektif yang signifikan antara kelas eksperimen dan kontrol. Hal tersebut juga dikuatkan dengan hasil angket respon siswa yang menunjukkan bahwa keseluruhan siswa kelas eksperimen menyatakan termotivasi untuk mempelajari Reaksi Redoks dengan media pembelajaran STEM. Motivasi siswa ditunjukkan dengan pernyataan bahwa siswa selalu membawa literatur (buku, hasil browsing, dll) saat pembelajaran materi reaksi redoks berlangsung, terkecuali terdapat $15,2 \%$ siswa yang tidak selalu membawa literatur saat pembelajaran berlangsung.

Kemampuan afektif siswa kelas eksperimen dan kontrol dievaluasi dengan menggunakan lembar penilaian afektif yang dan penilaian diri (self-assesment). Berdasarkan Tabel 6 dapat diketahui bahwa siswa kelas eksperimen memperoleh nilai afektif yang lebih tinggi daripada kelas kontrol. Standar minimum ketuntasan afektif adalah kategori baik (B) (Depdikbud, 2013). Berdasarkan standar tersebut, terdapat 4 siswa kelas eksperimen dan 8 siswa kelas kontrol yang masih memiliki nilai di bawah standar. Berdasarkan hasil lembar penilaian diri pada siswa, jumlah siswa yang memperoleh nilai tidak tuntas pada kelas kontrol lebih banyak daripada kelas eksperimen disebabkan karena siswa kurang termotivasi mempelajari materi reaksi redoks dengan metode konvensional.

Berdasarkan Tabel 6 juga dapat diketahui bahwa kenaikan hasil belajar kognitif (dihitung dari selisih antara nilai pre tes dan pos tes) dan hasil belajar afektif siswa kelas eksperimen lebih tinngi dibandingkan kelas kontrol.
Tabel 6. Data Rata-rata Nilai Kognitif, Afektif dan Psikomotor Kelas Eksperimen dan Kontrol

\begin{tabular}{cccc}
\hline Hasil Belajar & $\begin{array}{c}\text { Kelas } \\
\text { Eksperimen }\end{array}$ & $\begin{array}{c}\text { Kelas } \\
\text { Kontrol }\end{array}$ \\
\hline Kognitif & $\begin{array}{c}\text { Rata-rata } \\
\text { Pre tes }\end{array}$ & 2,9 & 2,9 \\
\cline { 2 - 3 } & $\begin{array}{c}\text { Rata-rata } \\
\text { Pos Tes }\end{array}$ & 7,8 & 7,4 \\
\cline { 2 - 3 } & $\begin{array}{c}\text { Selisih } \\
\text { rata-rata } \\
\text { nilai pre } \\
\text { tes dan pos } \\
\text { tes }\end{array}$ & 0,9 & 0,5 \\
\hline Afektif & 3,32 & 3,09 \\
\hline Psikomotor & 3,13 & - \\
\hline
\end{tabular}

Kemampuan psikomotor siswa kelas eksperimen memperoleh hasil yang baik dengan rata-rata nilai 3,13. Semua siswa kelas eksperimen mendapatkan nilai psikomotor di atas KKM sehingga dapat disimpulkan bahwa siswa dapat melakukan percobaan pengukuran kadar gas $\mathrm{CO}_{2}$ yang dihasilkan dari reaksi pembakaran alkohol dan pembakaran gula dengan prosedur yang baik dan benar. Sedangkan penilaian psikomotor untuk kelas kontrol tidak dilakukan karena tidak terdapat aktivitas yang melibatkan gerakan fisik dan keterampilan tangan selama pembelajaran berlangsung (Depdikbud, 2008).

Siswa yang berada pada kelas eksperimen mengemukakan pendapatnya mengenai pembelajaran kimia terintegrasi berbasis STEM dengan menggunakan sensor gas $\mathrm{CO}_{2}$ pada materi Reaksi Redoks melalui angket respom siswa yang diberikan. Hasil dari angket tersebut menunjukkan bahwa $87,9 \%$ siswa belum pernah mempelajari kimia dengan menggunakan sistem pendeteksi gas. Hal tersebut menunjukkan bahwa mempelajari Reaksi Redoks dengan media sensor gas merupakan pengalaman baru bagi siswa. Dalam prakteknya, sebanyak $84,8 \%$ siswa mampu mengoperasikan sistem pendeteksi gas $\mathrm{CO}_{2}$ dengan sangat baik dan $15,2 \%$ siswa mampu mengoperasikan dengan baik. Dengan adanya pernyataan dari siswa tersebut dapat diketahui bahwa sistem pendeteksi gas $\mathrm{CO}_{2}$ mudah dioperasikan oleh siswa.

Selanjutnya, mayoritas siswa kelas eksperimen menyatakan bahwa mempelajari Reaksi Redoks dengan sistem pendeteksi gas lebih mudah dibandingkan dengan 
pembelajaran konvensional. Namun terdapat sebanyak 3\% siswa menyatakan kurang setuju dengan pernyataan tersebut karena kesulitan dalam menganalisis reaksi redoks yang terlibat pada permukaan sensor gas $\mathrm{CO}_{2}$. Keseluruhan siswa pada kelas eksperimen menyatakan bahwa mempelajari reaksi redoks dengan menggunakan sistem pendeteksi gas $\mathrm{CO}_{2}$ lebih menarik daripada pembelajaran konvensional dengan rincian $6,1 \%$ menyatakan cukup setuju, $75,8 \%$ menyatakan setuju, dan $18,2 \%$ menyatakan sangat setuju terhadap pernyataan tersebut. Hasil penelitian ini sejalan dengan penelitian yang telah dilakukan oleh $\mathrm{Chi}, \mathrm{H}$. dan Jain, H. (2011) dan Hinze (2013) yang berhasil dalam penggunaan media pembelajaran berbais STEM di kelas. Dengan demikian, pembelajaran kimia terintegrasi dengan media sistem pendeteksi gas $\mathrm{CO}_{2}$ merupakan inovasi yang menarik dan dapat meningkatkan hasil belajar bagi siswa sekolah menengah.

\section{Simpulan dan Saran}

Simpulan

Media pembelajaran berbasis STEM yang terdiri atas sensor gas karbon dioksida dan modul STEM telah diterapkan pada pembelajaran kimia SMK Negeri 5 Surabaya pada materi reaksi redoks. Hasil validasi media pembelajaran kimia terintegrasi berbasis STEM sebelumnya telah dilakukan untuk menilai kelayakan media sebelum diterapkan. Hasil validasi menunjukkan bahwa media pembelajaran memiliki kriteria valid (layak digunakan untuk media pembelajaran). Hasil penerapan media pembelajaran menunjukkan adanya perbedaan hasil pencapaian kompetensi yang cukup signifikan (kognitif, afektif, dan psikomotor) antara siswa yang mengikuti pembelajaran reaksi redoks dengan pembelajaran STEM dan siswa yang mengikuti pembelajaran dengan metode konvensional. Rata-rata nilai kognitif siswa setelah pembelajaran berlangsung adalah 7,8 pada kelas eksperimen dan 7,4 (0-10) pada kelas kontrol. Sedangkan nilai afektif siswa pada kelas eksperimen memperoleh rata-rata nilai 3,32 dan siswa kelas kontrol memperoleh rata-rata nilai 3,09 (0-4).
Saran

Berdasarkan simpulan hasil penelitian, beberapa hal yang dapat disarankan adalah perlu dilakukan penelitian lebih lanjut mengenai efektivitas penggunaan media pembelajaran berbasis STEM dengan topik sistem pendeteksi gas $\mathrm{CO}_{2}$ di SMA. Selain itu, Pengembangan media pembelajaran STEM dalam bentuk inovasi lain juga perlu dilakukan pada level sekolah menengah maupun perguruan tinggi untuk meningkatkan kegiatan pembelajaran yang bersifat multidisipliner.

\section{Ucapan Terima Kasih}

Peneliti mengucapkan terima kasih setinggi-setingginya atas bantuan biaya penelitian BOPTN yang diberikan oleh Direktorat Jenderal Pendidikan Tinggi (DIKTI) sehingga penelitian ini dapat berjalan dengan lancar.

\section{Daftar Pustaka}

Aksela, M. K. (2011), “Engaging Students for Meaningful Chemistry Learning Through Microcomputer-based Laboratory (MBL) Inquiry", Educació Química EduQnúmero, Vol. 9, hal. 3037.

Anderson, R. G. W. (2013), "Chemistry Laboratories, and How They Might be Studied", Studies in History and Philosophy of Science, Vol.44, hal. 669-675.

Barrett, B.S., Moran, A.L., dan Woods, J.E. (2014), "Meteorology Meets Engineering: An Interdisciplinary Stem Module For Middle and Early Secondary School Students", International Journal of STEM Education, hal. 1-6.

Chi, H., dan Jain, H. (2011), "Teaching Computing to STEM Students Via Visualization Tools", Procedia Computer Science, Vol.4, hal. 19371943.

Depdikbud. (2008), Pengembangan Perangkat Penilaian Psikomotor, Departemen Pendidikan dan Kebudayaan, Jakarta.

Depdikbud. (2013), Peraturan Menteri Pendidikan dan Kebudayaan Nomor 
69 Tahun 2013 tentang Kerangka

Dasar dan Struktur Kurikulum

Sekolah Menengah Atas/ Madrasah

Aliyah, Departemen Pendidikan dan

Kebudayaan, Jakarta.

Depdikbud. (2013), Peraturan Menteri Pendidikan dan Kebudayaan Nomor 66 Tahun 2013 tentang Standar Penilaian Pendidikan, Departemen Pendidikan dan Kebudayaan, Jakarta

Figaro Engineering Inc. (2004), TGS 4160 for The Detection of Carbon Dioxide, Japan. Diakses tanggal 12 J5nuari 2015 dari http://www.figarosensor.com/prod ucts.html.

Handelsman, Jo. May, D. E., Beichner, R., Bruns, P., Chang, A., DeHaan, R., Gentile, J., Lauffer, S., Stewart, J., Tilghman, S. M., Wood, W. B. (2010), "Scientific Teaching", Science New Series, Vol. 304, No. 5670, hal. 521522.

Hanover Research. (2011), K-12 STEM Education Overview, District Administration Practice, Washington, DC.

Hinze, S. R., Rapp, D. N., Williamson, V. M., Shultz, M. J., Deslongchamps, G., Williamson, K. C. (2013), "Beyond ball-and-stick: Students' Processing of Novel STEM Visualizations", Learning and Instruction, Vol. 26, hal.12-21.

Inel, D., dan Balim, A. G. (2013), "Concept Cartoons Assisted Problem Based Learning Method in Science and Technology Teaching and Students' Views", Procedia-Social and Behavioral Sciences, Vol. 93, hal. 376380.

ITEA. (2009), The Overlooked STEM Imperatives: Technology and Engineering $K-12 \quad$ Education, International Technology Education Association, United States.

Jeenthong, T., Ruenwongsa, P., dan Sriwattanarothai, N. (2014), "Promoting Integrated Science Process Skills Through Betta-live Science Laboratory", Procedia-Social and Behavioral Sciences, Vol. 116, hal. 3292-3296.

Johnson, L., Adams Becker, S., Estrada, V., and Martín, S. (2013), Technology Outlook for STEM+Education 2013-2018: An NMC Horizon Project Sector Analysis.
The New Media Consortium, Austin, Texas.

Juan, Llorens, A., dan Molina. (2011), "Problem Based Learning In Introductory Organic Chemistry: A Laboratory Activity Based On The Anti-Sprouting Effect Of Essential Oils", Australian Journal of Education Chemistry, Vol. 71, No. 2, hal. 6-12.

Klopfer, E., Osterwell, S., Groff, J., dan Haas, J. (2009), Using of Technology Today in the Classroom: The instructional Power of Digital Games ocial Networking Simulations and How Teachers Can Leverage Them, Massachusetts Institute of Technology.

Liu, X., Cheng, S., Liu, H., Hu, S., Zhang, D., Ning, H. (2012), "A Survey on Gas Sensing Technology”, Sensors, Vol. 12, hal. 9635-9665.

Nugent, G., Baker, B.S., Grandgenett, N., dan Adamchuk, V.I. (2010), "Impact of Robotics and Geospatial T echnology Interventions on Youth STEM Learning and Attitudes", Journal of Research on Technology in Education, Vol.42, No.4, hal. 391-408.

Omosewo, E. O. (2006), "The Laboratory Teaching Method in Science Based Disciplines", African Journal of Educational Studies, Vol. 4, No. 2, hal. 65-73.

Petrucci, R. H., Harwood, W. S., Herring, F. G., dan Madura, J. D. (2011), Prinsipprinsip dan Aplikasi Modern Edisi Kesembilan Jilid 1 (Terjemahan). Penerbit Erlangga, Jakarta.

Prasetyo, Y. D., Ikhsan, J., dan Sari, L. P. (2014), The Development of AndroidBased Mobile Learning Media As Chemistry Learning for Senior High School on Acid Base, Buffer Solution, and Salt Hydrolysis, Proceeding of International Conference on Research, Implementation and Education of Mathematics and Sciences, Malang: Universitas Negeri Malang.

Putra, R., P. (2013), Rancang Bangun Instalasi Listrik Otomatis Berbasis Mikrokontroler Arduino. Tugas Akhir Diploma, Jurusan Pendidikan Teknik Elektro, Fakultas Pendidikan Teknologi dan Kejuruan, Universitas Pendidikan Indonesia.

Saxton, E., Burns, R., Holveck, S., Kelley, S., Prince, D., Rigelman, N., dan Skinner, 
E. A. (2014), “A Common

Measurement System For K-12

STEM Education: Adopting An

Educational Evaluation Methodology

that Elevates Theoretical Foundations

and Systems Thinking", Studies in

Educational Evaluation, Vol. 40, hal. 18-35.

Shehu, Garba. (2015). "Two Ideas of Redox Reaction: Misconceptions and Their Chalenges in Chemistry Education". Journal of Research \& Methods in Education. Vol 5(1):15-20

Srisawasdi, N. (2012), 'Students' Teacher Perceptions of Computerized Laboratory Practise for Science Teaching: A Comparative Analysis", Procedia-Social and Behavioral Sciences, Vol. 46, hal. 4031-4038.

Wetchakun, K., Samerjai, T., Tamaekong, N., Liewhiran, C., Siriwong, C., Kruefu, V., Wisitsoraatb, A., Tuantranont, A., Phanichphant, S. (2011), "Semiconducting Metal Oxides As Sensors for Environmentally Hazardous Gases", Sensors and Actuators B, Vol. 160, No. 1, hal. 580591. 